University of Nebraska - Lincoln

DigitalCommons@University of Nebraska - Lincoln

February 2005

\title{
The Charles J. Kappler Indian Affairs: Laws and Treaties Internet Site at the Oklahoma State University
}

Charles D. Bernholz

University of Nebraska-Lincoln, cbernholz2@unl.edu

Suzanne L. Holcombe

Oklahoma State University, suzanne.holcombe@okstate.edu

Follow this and additional works at: https://digitalcommons.unl.edu/libraryscience

Part of the Library and Information Science Commons

Bernholz, Charles D. and Holcombe, Suzanne L., "The Charles J. Kappler Indian Affairs: Laws and Treaties Internet Site at the Oklahoma State University" (2005). Faculty Publications, UNL Libraries. 8.

https://digitalcommons.unl.edu/libraryscience/8

This Article is brought to you for free and open access by the Libraries at University of Nebraska-Lincoln at DigitalCommons@University of Nebraska - Lincoln. It has been accepted for inclusion in Faculty Publications, UNL Libraries by an authorized administrator of DigitalCommons@University of Nebraska - Lincoln. 
Published in Library Collections, Acquisitions, and Technical Services 29:1 (March 2005), pp. 82-89; doi 10.1016/j.lcats.2005.01.001 Copyright (C 2005 Elsevier Inc. Used by permission. http://0-www.sciencedirect.com/science/journal/14649055

Published online February 19, 2005.

\title{
The Charles J. Kappler "Indian Affairs: Laws and Treaties" Internet site at the Oklahoma State University
}

\author{
Charles D. Bernholz $†$ and Suzanne L. Holcombe $\ddagger$ \\ † Love Memorial Library, University of Nebraska, Lincoln, NE 68588, USA \\ (corresponding author: email cbernholz2@unl.edu, fax 402 472-5131) \\ $\ddagger$ Edmon Low Library, Oklahoma State University, Stillwater, OK 74078, USA \\ (email sholcom@okstate.edu, fax 405 744-7579)
}

\begin{abstract}
Indigenous nations and issues are a worldwide concern and a number of WWW resources that support multidisciplinary research in this area have been previously identified. The availability of such tools is a boon to cost-effective collection development. One of the previously selected electronic resources was the Indian Affairs: Laws and Treaties Internet site at the Oklahoma State University. ${ }^{1}$ This commentary describes more fully the use of this collection of treaties created between the Indian Nations and the U.S. federal government. Research examples are used to demonstrate the relationship of these documents to various indigenous issues.
\end{abstract}

Keywords: Collection development, electronic resources, American Indian treaties

\section{Introduction}

In a recent discussion highlighting selected World Wide Web resources regarding indigenous nations, Gina Matesic declared that the term indigenous peoples was "used inclusively, and [was] intended to respectfully encompass First Nations, Ab-

\footnotetext{
${ }^{1}$ URL: http://0-www.digital.library.okstate.edu.library.unl.edu/kappler/
} 
original, Indian, Inuit, and other peoples throughout the world."[1, p.16] Indeed, she noted that the United Nations' International Decade of the World's Indigenous People ${ }^{2}$ concludes in 2004, and that her materials on indigenous peoples reachjust like this International Decade program-beyond North America to include Latin and South America, Europe, Africa, Asia, and Oceania. The benefits of such collections are that these important and easily accessible Internet materials make investigation of indigenous issues available to almost every library, and that electronic resources are an expeditious way to create collections that are more robust and to reduce acquisition and technical services costs.

The note referred to, for example, the Indian and Northern Affairs Canada Web site $^{3}$ because it serves as "the central federal department for aboriginal matters in Canada." $[2$, p.17] This is an important connection because it provides immediate access to historic treaty texts and to materials germane to land claims submitted by recognized First Nations. ${ }^{4}$

Within the international community, Matesic provided the site for the text of the 1840 Treaty of Waitangi. ${ }^{5}$ This instrument between the Crown and the Maori of New Zealand proposed that the "acquisition of Land by the Crown for the future Settlement of British Subjects must be confined to such Districts as the Natives can alienate without distress or serious inconvenience to themselves." ${ }^{\prime 6}$ There is now a Waitangi Tribunal established by the New Zealand government as "a permanent commission of inquiry charged with making recommendations on claims brought by Maori relating to actions or omissions of the Crown, which breach the promises made in the Treaty of Waitangi." 7 This agency functions in a manner similar to that of Canada's Claims and Indian Government Sector in the Department of Indian Affairs and Northern Development.

In comparison, the United States created many more treaties with their indigenous peoples than did either Canada or New Zealand. Matesic mentioned a Web

${ }^{2}$ See http://www.unhchr.ch/indigenous/decade.htm for background information, and for a link to the text of United Nations General Assembly Resolution 48/163 of December 21, 1993 that proclaimed the purpose of this endeavor. This International Decade of the World's Indigenous People Web site and other sites reported in this article were last retrieved on December 27, 2004.

${ }^{3}$ This Canadian Government site is http://0-www.ainc-inac.gc.ca.library.unl.edu/index e.html.

${ }^{4}$ See http:/ / -www.ainc-inac.gc.ca.library.unl.edu/ps/clm/scb e.html for the two classes of claims available to petitioners under current federal policy: "Specific claims arise from Canada's breach or non-fulfillment of lawful obligations found in treaties, agreements or statutes (including the Indian Act). Comprehensive claims are based on unextinguished Aboriginal rights where no treaty has been signed" (emphasis added). Over 250 such claims have been settled in the last three decades.

${ }^{5}$ Matesic used a New Zealand government archives page for her introduction to the treaty text. The URL has been changed to http:/ / www.treatyofwaitangi.govt.nz/.

${ }^{6}$ See these August 14, 1839 instructions from the Colonial Secretary, Lord Normanby, to Capt. William Hobson at http:// www.treatyofwaitangi.net.nz/LordNormanbysBrief.html .

7 The main Web site of the Tribunal is at http://www.waitangi-tribunal.govt.nz/default.asp. Their declared vision is "that, having reconciled ourselves with the past and possessing a full understanding of the Treaty of Waitangi, Maori and non-Maori New Zealanders will be equipped to create a future for two peoples as one nation" (see http://www.waitangi-tribunal.govt.nz/about/waitangitribunal/ ). 
site that provides easy access to Charles J. Kappler's Indian Affairs: Laws and Treaties, a compilation that contains almost all of the recognized post-Independence treaty texts. ${ }^{8}$ This article describes its use more fully through research examples coupling the relationship of these documents to indigenous issues.

\section{U.S. federal Indian law resources}

The world of U.S. federal Indian law is a complex one. In the past, a number of critical resources have been created, most produced in traditional formats. In print, for example, the original and second editions of Felix Cohen's Handbook of Federal Indian Law [3] and [4] have served attorneys for decades, and this material has been brought up to date recently by a similar treatise.[5] Cases and Materials on Federal Indian Law[6] and American Indian Law in a Nutshell[7] convey the ever-growing complexities of this jurisprudence, "with all the attendant consequences for the tribes and their members, the states and their citizens, and the federal government." [8, p.1] In microform, the National Archives have captured the images of the original treaties with the tribes, [9] while the texts have been gathered in paper, originally via a series of volumes produced by the Government Printing Office. [10]

It is the relevance of these transactions with the tribes that underlie all of these assets. These documents contain the parameters under which Indian lands were ceded, and under which the federal government agreed to compensate or to assist the tribes. The collected texts of these instruments were compiled and edited by Charles J. Kappler, as the Clerk to the Senate Committee on Indian Affairs. The original five volumes detail laws, executive orders, proclamations, and treaties. The final texts of 366 of those treaties recognized by the Department of State, ${ }^{9}$ contained in volume 2 of the set, have been preserved also in stand-alone publications. [11] and [12]

Today, as Miller has demonstrated,[13] the availability of electronic resources has seized the legal world through a plethora of research databases, Web links, and pathfinders. The efficacy of these tools assists practicing attorneys, as well as law students in their career preparations and other investigators interested in these materials, and significant documents, especially the treaties, in the field of federal Indian law have been added now to this electronic realm. An example of the development of enhanced indexing of legal materials is the Oklahoma State

\footnotetext{
${ }^{8}$ The Kappler resource is available at http://0-digital.library.okstate.edu.library.unl.edu/kappler/ .

${ }^{9}$ There are 374 recognized treaties, plus the never formally promulgated Treaty of Fort Laramie with the Sioux, etc., 1851 that has been declared a valid treaty by the Courts (Moore v. United States, 1897; Roy v. United States, 1910).[21] and [22] The British, before the Revolutionary War, concluded the first seven treaties acknowledged by the Department of State, and the texts of two additional treaties are available in volume 1 of American State Papers: Indian Affairs, pp. 641 and 696, respectively, [23] or at http:/ /0-memory.loc.gov.library.unl. edu/ammem/amlaw/lwsp.html. These nine instruments are not included in Kappler's compilation. The Statutes at Large do not contain the text of the Treaty of Fort Laramie with the Sioux, etc., 1851 (11 Stat. 749), but it is available in Kappler's suite (1904, vol. 2, pp. 594-596)[24] and at http://0-digital.library.okstate.edu.library.unl.edu/kappler/Vol2/treaties/sio0594.htm .
} 
University Library's electronic version of Kappler's Indian Affairs: Laws and Treaties resource. ${ }^{10}$

\section{Research applications}

The fully searchable digitized text and page images facilitate the use of Kappler's collection. Several general research examples may demonstrate the usefulness and advantage over the paper copy of the second volume-devoted to treaty documents - on the OSU Indian Affairs: Laws and Treaties Web site. Similar applications, regarding the materials in the other six volumes, may be investigated with the same general search principles.

Two test scenarios will uncover the enhanced advantage of OSU's digitized version. There is only one treaty that confers whaling and sealing rights to a tribe. Neither of these two activities is listed in the paper format index to Kappler's second volume. However, searching the database version for the term "whaling" returns this lone document: the Treaty with the Makah, $1855 .{ }^{11}$ In a similar application, the names of individuals involved in treaty negotiations are not indexed either. Yet an electronic search for the name "Kit Carson" will reveal four treaties in which this legendary figure participated, ${ }^{12}$ while a search for "Sitting Bull" will return one document. ${ }^{13}$ In these examinations, the electronic resource with a search feature becomes invaluable.

${ }^{10}$ The details of the process used to create this project were presented by the second author[25] at the 9th Annual Federal Depository Library Conference; see http://0-www.access.gpo.gov.library.unl.edu/su_docs/

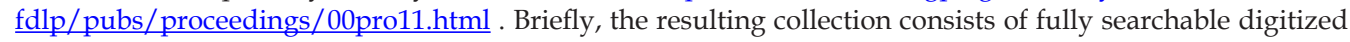
text plus page images. The original margin notations have been maintained, and tables of contents and indexes are furnished. In addition, there is a special "Treaties by Year" table of contents for the second, or treaties, volume. The text is available on the Web site with HTML markup and the images are available in .jpg format. For archival purposes, the text was coded and stored as SGML or XML using a modified version of the TEI Lite DTD, and the images were saved as .tif files. As OSU now uses data-driven Web sites to manage their electronic journal databases, a combination of a dedicated Microsoft SQL Server 2000 and Cold Fusion scripting supports Web searching through Innerprise spider or search engine software.

${ }^{11}$ The rights, that include the taking of fish, are noted in Article 4. The Statutes at Large citation for this treaty is 12 Stat. 939. See Kappler (1904, vol. 2, pp. 682-685) [26] or at http://0-digital.library.okstate.edu.library.unl.edu/ kappler/Vol2/treaties/mak0682.htm . This treaty is returned, along with nine other documents from volume two, by a search for the term "sealing." All but Makah use this expression in the "signing and sealing" sense.

12 The four treaties in which Carson served as a signatory were the Treaty with the Cheyenne and Arapaho, 1865 (14 Stat. 703; Kappler, 1904, vol. 2, pp. 887-891 or http://0-digital.library.okstate.edu.library.unl.edu/kappler/ Vol2/treaties/che0887.htm ); [27] the Treaty with the Apache, Cheyenne, and Arapaho, 1865 (14 Stat. 713; pp. 891-892 or http://0-digital.library.okstate.edu.library.unl.edu/kappler/Vol2/treaties/apa0891.htm ); the Treaty with the Comanche and Kiowa, 1865 (14 Stat. 717; pp. 892-895 or http://0-digital.library.okstate.edu.library.unl.edu/kappler/Vol2/treaties/com0892.htm ); and the Treaty with the Ute, 1868 (15 Stat. 619; pp. 990996 or http://0-digital.library.okstate.edu.library.unl.edu/kappler/Vol2/treaties/ute0990.htm ). At each event, Carson was listed as one of the "Commissioners on the part of the United States."

${ }^{13}$ Sitting Bull took part in the Treaty with the Sioux - Brule, Oglala, Miniconjou, Yanktonai, Hunkpapa, Blackfeet, Cuthead, Two Kettle, Sans Arcs, and Santee - and Arapaho, 1868 (15 Stat. 635; Kappler, 1904, vol. 2, pp. $998-1007$ or http://0-digital.library.okstate.edu.library.unl.edu/kappler/Vol2/treaties/sio0998.htm ). [28] His English name, Sitting Bull - and his Lakota name, Tah-Ton-Kah-He-Yo-Ta-Kah - appear in the section "Executed on the part of the Ogallalah band of Sioux by the chiefs and headmen whose names are hereto subscribed, they being thereunto duly authorized, at Fort Laramie, the twenty-fifth day of May, in the year A. D. 1868." [29, p. 1004] See the contemporary spelling of his Lakota name, Tatanka Iyotanka, and his well-known photograph by David F. Berry on the Dakota-Lakota-Nakota Human Rights Advocacy Coalition Web page ( http:// www.dlncoalition.org/dln_nation/chief_sitting_bull.htm ). 
In the Minnesota v. Mille Lacs Band of Chippewa Indians case before the U.S. Supreme Court, [14] extensive testimony was presented on behalf of the Band.[15] Further, three treaties - the Treaty with the Sauk and Foxes, 1837 (7 Stat. 543), the Treaty with the Winnebago, 1837 (7 Stat. 544), and the Treaty with the Winnebago, 1846 (9 Stat. 878) $)^{14-}$ were brought before the Supreme Court for the first time, demonstrating the contemporary relevance of these instruments. Each of these treaties may be retrieved and examined with the OSU Web resource, although comparable searching in the paper format is available as well. For example, the specific year ranges from the "Treaties by Year" table of contents for volume 2 may be employed, or the tribe name may be used as a search parameter in the Index, to find these documents. In the case of the Sauk and Foxes, 1837 treaty, care must be taken to select the correct text, as both instruments from 1837 may be retrieved: the required one is at 7 Stat. 543 and not at 7 Stat. 540 for the other Sauk and Foxes, 1837 one. The inclusion of Statutes at Large citations and date data in this digital collection facilitate identification. ${ }^{15}$

At the state level, there is also a rich array of cases that may be located by using specific treaty citations from the Statutes at Large to search within the Web-based LexisNexis resource, another tool for facilitated access to legal technicalities. This online legal database permits keyword searching through a broad array of legal reporters, for state as well as for federal case law. ${ }^{16}$ The following case was identified by this means within the Idaho State Case Law section of LexisNexis Academic Universe for the Statutes at Large citation - "12 Stat. 957" - of the Treaty with the Nez Perces, 1855. ${ }^{17}$

A Nez Perce man was arrested for fishing without a State fish and game license in a stream that ran originally within the Nez Perce reservation. The defense centered on Article 3 of the Treaty with the Nez Perces, 1855 that assured the qualified "right of taking fish at all usual and accustomed places in common with citizens of the Territory," and on two subsequent treaties ${ }^{18}$ that reconfirmed these rights. In citing the U.S. Supreme Court case Tulee v. Washington [16] and the similarity between the $1855 \mathrm{Nez}$ Perce treaty and the one under consideration in Tulee, ${ }^{19}$ the Su-

14 These three treaties are in Kappler (1904, vol. 2, pp. 497-498, 498-500, and 565-567) [30] or http://0-digital.library.okstate.edu.library.unl.edu/kappler/Vol2/treaties/sau0497.htm, http://0-digital.library.okstate.edu. library.unl.edu/kappler/Vol2/treaties/win0498.htm , and http://0-digital.library.okstate.edu.library.unl. edu/kappler/Vol2/treaties/win0565.htm .

${ }^{15}$ Another focused application may be seen in Bernholz.[31] In that analysis, a Web link was created between those opinions in Indian Territory Reports that cited treaties, and these electronic treaty texts in OSU's Kappler's Indian Affairs collection. Indian Territory Reports is a seven-volume compilation of cases determined by the U.S. Court of Appeals for the Indian Territory between February 1896 and September 1907. [32]

${ }^{16}$ The efficacy of such a search is made clear when there might be limited or no access to the various official reporters for the state. For example, cases before the Idaho Supreme Court may be found in the Pacific Reporter beginning in the year 1883 and/or in Idaho Reports from 1866 forward (The Bluebook, 2000, p. 200). [33]

17 See Kappler (1904, Vol. 2, pp. 702-706) [34] or http://0-digital.library.okstate.edu.library.unl.edu/kappler/ Vol2/treaties/nez0702.htm .

18 The Treaty with the Nez Perces, 1863 (14 Stat. 647; Kappler, 1904, vol. 2, pp. 843-848 or http://0-digital.library. okstate.edu.library.unl.edu/kappler/Vol2/treaties/nez0843.htm ), [35] and the Treaty with the Nez Perces, 1868 (15 Stat. 693; pp. 1024-1025 or http://0-digital.library.okstate.edu.library.unl.edu/kappler/Vol2/treaties/nez1024.htm ).

19 The Treaty with the Yakima, 1855 (12 Stat. 951; Kappler, 1904, vol. 2, pp. 698-702 or http://0-digital.library.okstate.edu.library.unl.edu/kappler/Vol2/treaties/yak0698.htm ) [36] was concluded at the same council site 2 days earlier than the Treaty with the Nez Perces, 1855 by the same negotiating team led by Isaac I. Stevens, the Governor and Superintendent of Washington Territory. 
preme Court of Idaho concluded that "the Tulee case is a comprehensive and complete vindication of the right of the Indian to fish without a license by reason of the rights reserved to him, not granted, in the original treaty and by successive treaties reaffirmed, or, at least, not abrogated." [17]

This Treaty with the Nez Perces, 1855 was 1 of 10 treaties negotiated by Isaac I. Stevens, the governor of Washington Territory in 1854 and 1855. [18, pp. 402-409], [19, pp. 250-255] Aspects of this Nez Perces treaty have been argued before all levels of the court system. A search of the online LexisNexis "Federal and State Cases" option yields 21 citations to cases before the U.S. Supreme Court, Court of Appeals of the Ninth District, Circuit Court of Appeals for the Ninth District, Circuit Court for the District of Idaho, District Courts in Idaho and Oregon, and Court of Claims, and before the Supreme Courts of Idaho, Michigan, and Washington. Many of the State cases concern the permissibility of hunting, fishing, and/or gathering, while other federal proceedings examine the land cession process. The prompt electronic retrieval of these specific case opinions and of the underlying treaty document is a demonstration of the intersection of technology and of legal materials that has brought about more effective investigations of federal Indian law. This is especially crucial here because of the varied applications of the aspects of this single instrument. This wider scope makes it imperative that this treaty be consulted when examining actions taken by each of the petitioners.

Further, a focused discussion of fishing rights would also benefit from the awareness that this treaty, and others in the Stevens suite, contain the frequently used phrase "at all usual and accustomed places" that has affected off-reservation gathering issues for the last century. ${ }^{20}$ The Indian Affairs: Laws and Treaties Web site can provide such access. A search for the name "Isaac I. Stevens" returns the 10 relevant Washington Territory treaties, while a search for the term "accustomed" yields the nine treaties that contain this critical word. ${ }^{21}$ Both of these searches are faster and more accurate than perusing the paper text of Indian Affairs: Laws and Treaties, particularly for investigators unfamiliar with the area of Indian treaties.

The OSU Indian Affairs: Laws and Treaties Web site and other electronic resources therefore have a distinct place in the repertoire of those interested in federal Indian law, and particularly in the parameters of the treaties between the Indian Nations and the federal government. It provides worldwide access to data that may be physically held by only a handful of institutions. ${ }^{22}$ This site is also a pertinent dem-

${ }^{20}$ See, specifically, United States $v$. Winans [37] and the remarks of Cohen, [38, pp. 285-286] Strickland, [39, pp. 450-456] and Meyers and Smith [40, pp. 315-329] on off-reservation hunting and fishing rights, and the concept of "usual and accustomed fishing grounds and stations." Lewis comments expressly on these fishing rights in the Stevens treaties. [41]

21 There are three versions of this "accustomed" phrase in 9 of the 10 Stevens treaties. "Accustomed places" appears in three treaties; "accustomed grounds and stations" is in five instruments; and "accustomed stations" is used in one document. The Treaty with the Makah, 1855 that conferred whaling and sealing rights is one of the "accustomed grounds and stations" examples. The tenth Stevens document, the Treaty with the Blackfeet, 1855 (Kappler, 1904, vol. 2, pp. 736-740 or http:/ /0-digital.library.okstate.edu.library.unl.edu/kappler/ Vol2/treaties/bla0736.htm ) [42] does not discuss fishing in this detail.

22 The WorldCat (see http://0-www.oclc.org.library.unl.edu/worldcat/ ) indicates that less than 500 libraries around the world have the complete seven-volume paper version of Indian Affairs: Laws and Treaties. 
onstration of, and model for, the usefulness of digitized texts and images for legal and scholarly investigations. In its creation, this research tool fulfills Matesic's proposal [20, p. 16] that "[1]ibrarians in the field must perceive library resources in the broadest manner to be most effective" for their potential patrons. Electronic resources like the OSU Indian Affairs: Laws and Treaties Web site provide easy, cost-effective access to important collection development options for all libraries.

\section{References}

[1] G. Matesic, Indigenous nations: Sites of interest, College and Research Libraries News 65 (2004), pp. 16-19.

[2] Ibid.

[3] F. S. Cohen, Handbook of federal Indian law, Government Printing Office, Washington, DC (1942).

[4] R. Strickland, Felix S. Cohen's handbook of federal Indian law, Michie, Charlottesville, VA (1982).

[5] H. Meyers and C. Smith, American Indian law deskbook (3rd ed.), University Press of Colorado, Boulder, CO (2004).

[6] D .H. Getches, C. F. Wilkinson and R. A. Williams, Cases and materials on federal Indian law (4th ed.), West Group, St. Paul, MN (1998).

[7] W. C. Canby, American Indian law in a nutshell (3rd ed.), West Group, St. Paul, MN (1998).

[8] Ibid.

[9] Ratified Indian treaties, 1722-1869, National Archives and Records Service, Washington, DC (1966).

[10] Kappler, C. J. (1904-1941). Indian Affairs: Laws and Treaties (vols. 1-5). Washington, DC: Government Printing Office.

[11] C. J. Kappler, Indian treaties, 1778-1883, Amereon House, Mattituck, NY (1972).

[12] C. J. Kappler, Indian treaties, 1778-1883, Interland Publishing, New York (1972).

[13] S. R. Miller, Teaching advanced electronic legal research for the modern practice of law, Perspectives: Teaching Legal Research and Writing 9 (2001), pp. 120-123.

[14] Minnesota v. Mille Lacs Band of Chippewa Indians, 526 U.S. 172 (1999).

[15] J. M. McClurken, Fish in the lakes, wild rice, and game in abundance: Testimony on behalf of Mille Lacs Ojibwe hunting and fishing rights, Michigan State University Press, East Lansing, MI (2000).

[16] Tulee v. Washington, 315 U.S. 681 (1942).

[17] State v. McConville, 139 P.2d 485 (1943).

[18] F. P. Prucha, The great father: The United States Government and the American Indians, University of Nebraska Press, Lincoln, NE (1984).

[19] F.P. Prucha, American Indian treaties: The history of a political anomaly, University of California Press, Berkeley, CA (1994).

[20] Matesic.

[21] Moore v. United States, 32 Ct. Cl. 593 (1897).

[22] Roy v. United States, 45 Ct. Cl. 177 (1910).

[23] American state papers: Indian Affairs Vol. 1, Gales and Seaton, Washington, DC (1832).

[24] Kappler (1904-1941). 
[25] Holcombe, S. L. (2000). Bringing Indian Affairs: Laws and Treaties to the World Wide Web. Paper presented at the 9th Annual Depository Library Conference, Washington, DC. http://0-www. access.gpo.gov.library.unl.edu/su_docs/fdlp/pubs/proceedings/00pro11.html Accessed December 27, 2004.

[26] Kappler. (1904-1941).

[27] Ibid.

[28] Ibid.

[29] Ibid.

[30] Ibid.

[31] C. D. Bernholz, Federal Indian Law Internet tools: Indian Territory Cases at the Oklahoma State Courts Network and Kappler's Indian Affairs: Laws and Treaties at the Oklahoma State University, Journal of Government Information 30 (2004), pp. 637-647.

[32] Craig, J. F., \& Kellogg, F. H. (1900-1909). Indian Territory Reports: Cases Determined in the United States Court of Appeals for the Indian Territory (Vols. 1-7), Parsons, KS: Foley Railway Printing Co.

[33] The Bluebook: A Uniform System of Citation, Harvard Law Review Association, Cambridge, MA (2000) (17th ed.).

[34] Kappler (1904-1941).

[35] Ibid.

[36] Ibid.

[37] United States v. Winans, 198 U.S. 371. (1905).

[38] Cohen.

[39] Strickland.

[40] Meyers \& Smith.

[41] O.Y. Lewis, Treaty fishing rights: A habitat right as part of the trinity of rights implied by the fishing clause of the Stevens Treaties, American Indian Law Review 27 (2002), pp. 281-311.

[42] Kappler (1904-1941). 